\title{
Feed Resources and Livestock Production Situation in the Highland and Mid Altitude Areas of Horro and Guduru Districts of Oromia Regional State, Western Ethiopia
}

\author{
Kassahun Gurmessa ${ }^{1 *}$, Taye Tolemariam ${ }^{1}$, Adugna Tolera ${ }^{2}$, Fekadu Beyene $^{3}$ \\ and Solmon Demeke ${ }^{1}$ \\ ${ }^{1}$ College of Agriculture and Veterinary Medicine, Jimma Univesrity, P. O. Box: 307, Jimma, Ethiopia \\ ${ }^{2}$ School of Animal and Range Sciences, College of Agriculture, Hawassa University, P.O.Box: 222, \\ Hawassa, Ethiopia \\ ${ }^{3}$ Department of Food Science and Technology, Wollega University, P.O.Box: 395, Nekemte, Ethiopia
}

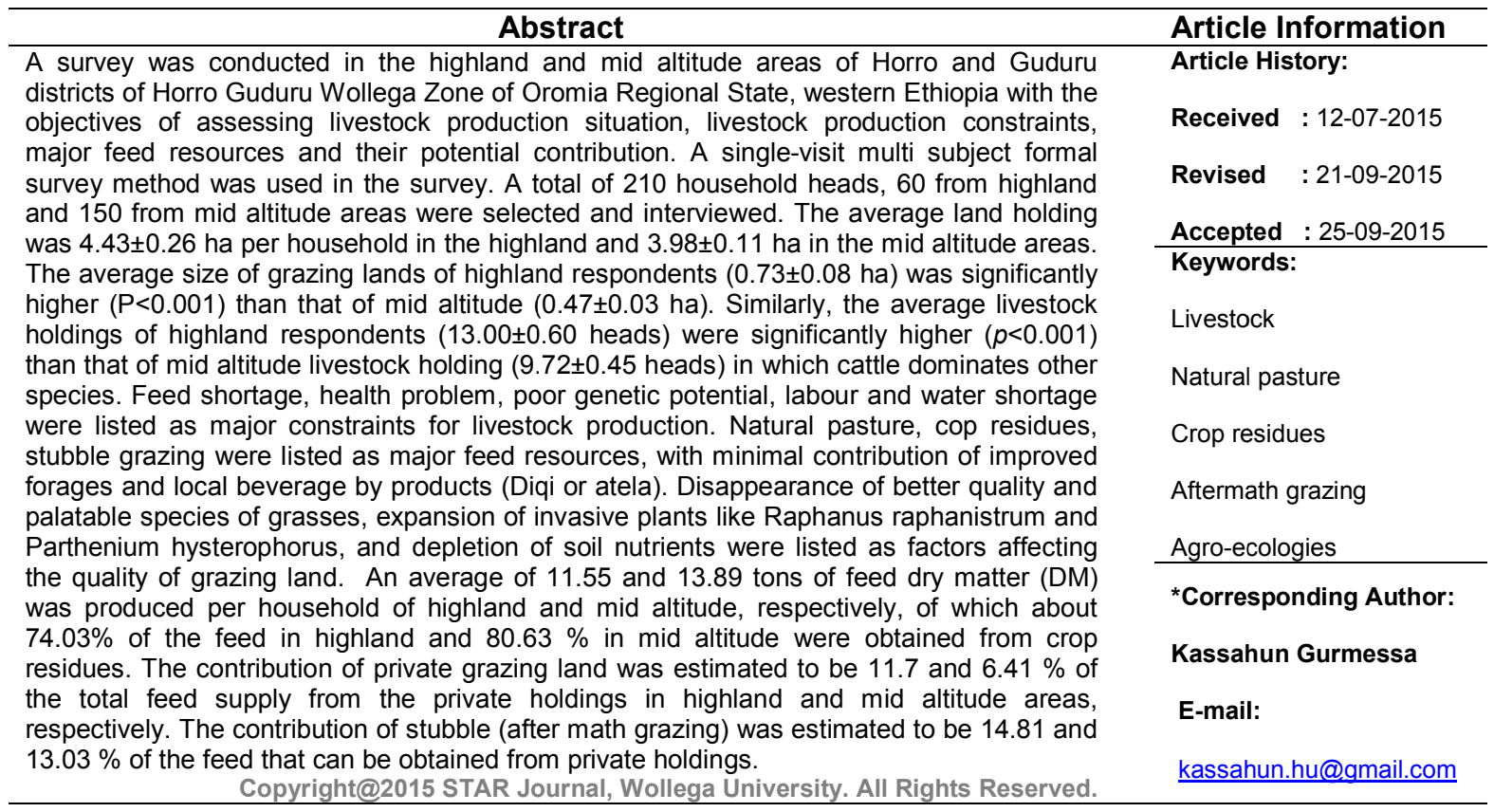

\section{INTRODUCTION}

Agriculture contributes $47 \%$ of the country's GDP and more than $80 \%$ of the export earning and employs over $85 \%$ of the population of Ethiopia. The livestock sector contributes $16.5 \%$ of the total GDP, $45 \%$ of agricultural GDP (Behnke, 2010) and $37-87 \%$ of the household incomes (MOFED, 2011). Ethiopia is endowed with high livestock population distributed in the different agro ecological zones of the country (Alemayehu 2006). The commonly available livestock feed resources include natural pastures, crop residues, improved forage and agro industrial products (Adugna et al., 2012).

In the highlands where mixd crop livestock production system predominates, the areas of grazing lands are highly fragmented and limited to areas where conditions are adverse for cropping due to topographic, edaphic and climatic conditions. According to CSA (1998) about 93.5\% of the highlands are allotted for temporary and permanent crops. Therefore, crop and livestock sub sectors compete for scarce farm resources causing inadequate feed supply, both in quality and quantity (Adugna et al., 2000). As a result, livestock productivity is generally lower than the potential (EARO, 1998; CSA, 2013). This is true in Horro and Guduru districts as well.

This necessitates assessment of the livestock production situation, feed resources availability and the prevailing livestock feeding practices in order to better 
Kassahun Gurmessa et alo,

understand the system and alleviate the constraints. Therefore, this study was initiated with the objectives of assessing the livestock production situation, livestock production constraints, available feed resources in relation to requirements of livestock in Horro and Guduru districts of Oromia Regional State, western Ethiopia.

\section{MATERIALS AND METHOD}

\section{Description of the Study Area}

The study was conducted in Horro and Guduru districts of Horro Guduru Wollega Zone of Oromia Regional state, Western Ethiopia. The two districts are found between $36^{\circ}-37^{\circ} \mathrm{E}$ longitudes and $9^{\circ}-10^{\circ} \mathrm{N}$ latitude. Horro district has 22 kebeles (the lowest administrative unit). It lies in altitude range of $1450-3100$ m.a.s.l.with annual rainfall ranges of $900-1800 \mathrm{~mm}$ and mean daily temprature ranging from 11.8 to $22.7^{\circ} \mathrm{C}$. Guduru district has 28 kebeles. It lies between an altitude ranges of 1500 - 2296 m.a.s.I., with annual rainfall range of 1000-2400 $\mathrm{mm}$ and average daily temperature varing from $14.9{ }^{\circ} \mathrm{C}$ to $17.5^{0} \mathrm{C}$. The climate of the two study areas are characterised by two distinct seasons, rainy (Gana) and dry (Bona). The two districts have one long rainy season extending from March to mid-October (Buzuayehu, 2006; Ayantu, 2013).

\section{Sampling Technique}

A single-visit multi subject formal survey method (ILCA, 1990) was used in the study. The districts were clustered into highland and mid altitude agroecologies.Then, 2 kebeles from the highland and 5 kebeles from the mid altitude areas were purposively selected according to the size of the two agro-ecologies and 30 household heads were randomly selected from each kebele for interview. The criteria for selection of the respondents included livestock holding, accessibility and experience of keeping livestock. Thus, 60 respondents from the highland and 150 respondents from mid-altitude giving a total of 210 respondents.

\section{Types of Data and Methods of Data Collection}

Data was collected both from primary and secondary sources. The primary data was collected from smallholder farmers using semi-structured questionnaire. Focuse group discussions with experienced farmers were made at each Kebele.The questionnaire was first pre tested before the commencement of the survey and filled by trained enumerants with close supervision of the first author.

\section{Estimation of Annual Feed Resources and Livestock Feed Requirement}

For herbage yield estimation of grassland, twenty representative enclosures, ten from highland and ten from mid altitude were selected by ealderly people. Then three samples at quadrat size of $0.5 \mathrm{mx} 0.5 \mathrm{~m}$ were taken from the selected grazingland diagonally at 10 meter difference
Sci. Technol. Arts Res. J., July-Sep 2015, 4(3): 111-116

for each of the two agro-ecologies. The samples were harvested by hand using sickle at approximately $2 \mathrm{~cm}$ above the ground (Mannetje, 1978). For estimating biomass yield fresh samples were dried at $105{ }^{\circ} \mathrm{C}$ for 24 hours. Then the dry matter (DM) obtained from different sites were used for extrapolation of total dry matter obtained from hectare of land per household.

The quantity of feed dry matter (DM) obtained from crop residues (maize stover, straws of wheat, barley and teff, etc) per household was estimated from crop yield to crop residue ratio using conversion factors of FAO (1987). The quantity of crop residue on the basis of DM available and those actually available for livestock consumption was estimated by deducting $10 \%$ of the same as wastage (Adugna and Said, 1994). The quantity of feed DM obtained annually from aftermath was estimated by multiplying the area of cultivated land by $0.5 \mathrm{tDM} / \mathrm{ha} / \mathrm{year}$ (FAO, 1987). The livestock population per household was converted to tropical livestock unit (TLU) as recommended by Gryseels (1988) and Abidinasir (2000). The DM requirement was calculated based on daily DM requirement of $250 \mathrm{~kg}$ dual purpose tropical cattle (an equivalent of one TLU) for maintenances according to Kearl (1982).

\section{Statistical Analysis}

Primary data from surveyed households was organized and analyzed using Statistical Package for Social Science (SPSS version 17.0). Mean and percentage values of various parameters were compared between the two study locations and inidices were calculated for ranking data using the formula: Index $=\sum$ of [3 for rank $1+2$ for rank $2+1$ for rank 3] for overall reasons/criteria.

\section{RESULTS AND DISCUSION}

\section{Household Characteristics}

The average family size of respondents in the highland was $7.12 \pm 0.31$ persons and that of the mid altitude area was $6.87 \pm 0.23$ persons with no significant difference $(p>0.05)$ between the two agro-ecological areas. Average family size of the surveyed households were similar with the family size reported for Fogera, Jeldu, Diga districts and Central highlands of Ethiopia having similar agroecologies and livestock production system (Bedasa et al., 2012; Ayele et al., 2012: Ahimed et al., 2010 and Desta et al., 2002). However, the result was lower than 9.92 persons reported for Adami-Tullu Jiddo-Kombolcha district (Dawit et al., 2013) but higher than national average of 4.9 persons per household reported for rural areas Ethiopia (EDHS, 2012; Tegene et al., 2015). The comparatively large family size reported in the current study could be due to lack of awareness towards family planning measures and the local perception of considering large family size as an asset for agricultural activities.

Table 1: Mean age (mean \pm SE) structure of the surveyed households

\begin{tabular}{ccccc}
\hline \multirow{2}{*}{ Variables } & High land & Mid altitude & Overall & \multirow{2}{*}{ Significance } \\
\cline { 2 - 4 } & $\mathbf{N}=\mathbf{6 0}$ & $\mathbf{N}=\mathbf{1 5 0}$ & $\mathbf{N = \mathbf { 2 1 0 }}$ & \\
\hline Average age of respondents (year) & $40.32 \pm 1.02$ & $41.39 \pm 0.91$ & $41.08 \pm 0.71$ & NS \\
House hold size & $7.12 \pm 0.31$ & $6.87 \pm 0.23$ & $6.94 \pm 0.18$ & $\mathrm{NS}$ \\
Male & $4.02 \pm 0.21$ & $3.42 \pm 0.13$ & $3.59 \pm 0.12$ & $*$ \\
Female & $3.10 \pm 0.20$ & $3.45 \pm 0.14$ & $3.35 \pm 0.11$ & $\mathrm{NS}$ \\
\hline
\end{tabular}

$\mathrm{N}=$ number of respondents, $\mathrm{NS}=$ non significant, ${ }^{*}, p<0.05$ 
Kassahun Gurmessa et alo,

\section{Landholding and Land Use Pattern}

Mean landholding and land use pattern of surveyed households is shown in Table 2. The average private land holding $(4.43 \pm 0.26 \mathrm{ha})$ of highland respondents was not significantly different $(p>0.05)$ from mean land holding $(3.98 \pm 0.11 \mathrm{ha})$ of respondents from the mid altitude area. Comparable size of landholding of $3.78 \mathrm{ha} / \mathrm{hh}$ reported for Mulo Sululta area of Selale (Desta et al., 2002). The average landholding reported in this study area is also comprable with the report of (Zelalem, 1999) who observed $4.9 \mathrm{ha} / \mathrm{hh}$ and $3.0 \mathrm{ha} / \mathrm{hh}$ for Holeta and Selale areas of Central Ethiopia, respectively and larger than 2.5 and $1.55 \mathrm{ha} / \mathrm{hh}$ reported for Dendi and Bure district (Belay et al., 2012; Shitahun et al., 2009). Larger landholding is assumed to provide an opportunity for land allocation to
Sci. Technol. Arts Res. J., July-Sep 2015, 4(3): 111-116

grazing lands, while the current study and overall scenario in Ethiopia tends to prioritize the available small land size for crop production.

There was no significant difference $(p>0.05)$ between the two agro-ecologies in the average holding of cultivated land, whereas the average area of private grazing land was significantly $(p<0.001)$ higher in the highland than in the mid-altitude area. The difference in the amount of grazing land between the two agro-ecologies could be seen as a result of the absence of bordering lowlands around study areas of Horro highlands that could be used to move livestock during pick feed shortage after all the land is cultivated.

Table 2: LSM and SE for land holding (ha) and use pattern per household of the respondents

\begin{tabular}{ccccc}
\hline Land use & $\begin{array}{c}\text { HIGHLAND } \\
(\mathbf{N}=\mathbf{6 0})\end{array}$ & $\begin{array}{c}\text { Mid altitude } \\
(\mathbf{N}=\mathbf{1 5 0})\end{array}$ & $\begin{array}{c}\text { Overall } \\
\mathbf{N = 2 1 0}\end{array}$ & Significance \\
\hline Cultivated & $3.70 \pm 0.26$ & $3.51 \pm 0.11$ & $3.56 \pm 0.11$ & $\mathrm{NS}$ \\
Grazing land & $0.73 \pm 0.08$ & $0.47 \pm 0.03$ & $0.54 \pm 0.03$ & $* * *$ \\
Total & $4.43 \pm 0.26$ & $3.98 \pm 0.11$ & $4.11 \pm 0.11$ & $\mathrm{NS}$ \\
\hline$* *=p<0.001 ; \mathrm{NS}=$ not significant; $\mathrm{N}=$ number of respondents; SE=standard error
\end{tabular}

\section{Livestock Holding}

The average livestock holding per household is summarized in Table 3 . The livestock species kept by farmers comprises of cattle, sheep, goats, donkeys, horses, and mules. The result shows that cattle is the dominant livestock species reared in both agro ecologies and there was no significant differnce $(p>0.05)$ in cattle holding between the two agro-ecologies. The higher proportion of cattle rearing in the two agro ecological areas could be due to high demand of cattle for cultivation and other farm activities in the area. Cattle breeds kept by the surveyed households are the local Horro breed. The overall average number of cattle holding of $9.74 \pm 0.39$ for highland and $9.24 \pm 0.43$ for mid altitude reported in present study areas were comparable with the previously reported values of 9.66 TLU for Selale (Kelay et al 2002) and 9.3 TLU for Horro (Edea et al., 2012). However, the average number of cattle holding in the current study was higher the average livestock holding of 4.53 TLU of cattle holding that was reported by Belay et al. (2012) for central Ethiopia. On the other hand, Solomon et al. (2014) reported higher livestock holdings for Pawe, Dibase, Wombara and Guba districts of Metekel Zone of Benishangul-Gumuz Region in western Ethiopia.
The sheep and goats holdings were significantly $(p<0.001)$ higher in the highlands than in the mid-altitude area, which could be due to the presence of higher area of grazing land in highland than mid-altitude area (Table 2). The number of donkeys held in both study agroecologies seems similar, but numerically large number of donkeys were kept in mid altitude areas. The number of horses and mules kept per household were significantly higher $(p<0.001)$ in the highland than in mid altitude area. This could be attributed to more suitability of the highland for horse and mule rearing with lower incidences of diseases and larger area of grazing land as compared to the mid-altitude area.

The overall livestock holding of $13.0 \mathrm{TLU} / \mathrm{hh}$ in the highland was significantly higher $(p<0.05)$ than that of the mid-altitude area (9.7 TLU/hh). The total livestock holding in the current study is comparable with previous reports for Dendi district of West Shewa Zone of Oromia Regional State (Belay et al., 2012; ZEdea et al., 2012) but higher than that the values reported for mid-altitude areas of Borena Zone (Dejene, 2014) and for Central Highlands of Ethiopia (Ahimed et al., 2010) as well as for Diga, Jeldu and Fogera districts (Bedassa et al., 2012).

Table 3: Least square mans \& standard errors for livestock holdings per household of the respondents in the study area

\begin{tabular}{|c|c|c|c|c|}
\hline Specises & $\begin{array}{c}\text { Highland } \\
(\mathrm{N}=60)\end{array}$ & $\begin{array}{c}\begin{array}{c}\text { Mid altitude } \\
(\mathrm{N}=150)\end{array} \\
\end{array}$ & $\begin{array}{l}\text { Overall } \\
(\mathrm{N}=210)\end{array}$ & Significance \\
\hline Cattle (TLU) & $9.74 \pm 0.39$ & $9.24 \pm 0.43$ & $9.38 \pm 0.33$ & NS \\
\hline Sheep (TLU) & $0.77 \pm 0.07$ & $0.18 \pm 0.02$ & $0.34 \pm .0 .03$ & $* * *$ \\
\hline Goats (TLU) & $0.60 \pm 0.07$ & $0.22 \pm 0.03$ & $0.33 \pm 0.03$ & $* * *$ \\
\hline Donkeys (TLU) & $0.54 \pm 0.07$ & $0.65 \pm 0.04$ & $0.62 \pm 0.03$ & NS \\
\hline Horses (TLU) & $2.56 \pm 0.27$ & $0.22 \pm 0.05$ & $0.89 \pm 0.11$ & $* * *$ \\
\hline Mule (TLU) & $0.11 \pm 0.04$ & $0.03 \pm 0.01$ & $0.05 \pm 0.02$ & * \\
\hline Total Livestock & $13.00 \pm 0.60$ & $9.72 \pm 0.45$ & $10.65 \pm 0.38$ & $* * *$ \\
\hline
\end{tabular}

\section{Constraints of Livestock Production}

The results of the semi-structured interview, focus group discussions and field observations revealed that feed shortage, disease and parasites, shortage of labor, low genetic potential of indigenous breeds, and water shortage were the main constraints affecting livestock production in both agro-ecologies of both districts in decreasing order of importance (Table 4). This is in line 
Kassahun Gurmessa et alo,

with previous studies in different parts of the country (Shitahun, 2009; Belay et al., 2012).

The problem of feed supply was reported by about $91.7 \%$ of respondents from the highland and $70.7 \%$ respondents from mid-altitude area. Feed and feed related problems such as shortage of feed supply, death of cattle due to bloating, less reproductive and productive performance of animals were listed as major constraints. During the wet season, the grazing lands in the study areas contain a significant proportion of clover (Trifolium
Sci. Technol. Arts Res. J., July-Sep 2015, 4(3): 111-116

species), which causes bloating and sudden death of cattle if grazed prior to full blooming. Similar reports of feed related problems were reported in other parts of Ethiopian highlands (Lemma 2002; Solomon 2004). This could be due to high protein, low energy, low fiber and low tannin content of the species which initiate foam formation during fermentation of feed in the reticulo-rumen leading to accumulation of gases produced (methane and carbon dioxide) as a result of fermentation of the consumed feed (Lees, 1992; Majak et al., 2003).

Table 4: Ranked constraints of livestock production as percived by surveyed households

\begin{tabular}{cclllll}
\hline \multirow{2}{*}{ Agro ecology } & \multirow{2}{*}{ Rank } & \multicolumn{5}{c}{ Constraints } \\
\cline { 3 - 7 } & & \multicolumn{1}{c}{ Feed } & Health & Genetic & Labor & Water \\
\hline \multirow{4}{*}{ High land } & $1^{\text {st }}$ & $55(91.7)$ & $5(8.3)$ & - & - & - \\
& $2^{\text {nd }}$ & $5(8.3)$ & $29(48.3)$ & $2(3.3)$ & $23(38.3)$ & $1(1.7)$ \\
& $3^{\text {rd }}$ & - & $18(30.0)$ & $12(20.0)$ & $15(25.0)$ & $15(25.0)$ \\
& $4^{\text {th }}$ & - & $8(13.3)$ & $40(66.7)$ & $10(16.7)$ & $2(3.3)$ \\
& $5^{\text {th }}$ & - & - & $6(10)$ & $12(20)$ & $42(70)$ \\
\cline { 2 - 7 } & Index & $\mathbf{0 . 3 3}$ & $\mathbf{0 . 2 3}$ & $\mathbf{0 . 1 4}$ & $\mathbf{0 . 1 9}$ & $\mathbf{0 . 1 1}$ \\
\hline \multirow{5}{*}{ Mid altitude } & $1^{\text {st }}$ & $106(70.7)$ & $27(18.0)$ & $11(7.3)$ & 2 & $4(2.7)$ \\
& $2^{\text {nd }}$ & $30(20)$. & $74(49.3)$ & $6(4.0)$ & $4(2.7)$ & $36(24.0)$ \\
& $3^{\text {rd }}$ & $10(6.7)$ & $41(27.33)$ & $46(30.7)$ & $36(23.3)$ & $17(11.3)$ \\
& $4^{\text {th }}$ & $3(2.0)$ & $5(3.3)$ & $41(27.3)$ & $74(34.0)$ & $27(18.0)$ \\
& $5^{\text {th }}$ & $1(0.7)$ & $3(2.0)$ & $46(12.7)$ & $34(25.3)$ & $66(44.0)$ \\
\cline { 2 - 7 } & Index & $\mathbf{0 . 3 1}$ & $\mathbf{0 . 2 5}$ & $\mathbf{0 . 1 5}$ & $\mathbf{0 . 1 4}$ & $\mathbf{0 . 1 5}$ \\
\hline
\end{tabular}

\section{Feed Resources and Availability}

Natural pasture, crop residues, stubble grazing, improved forages and local beverage by-products (Diqi or atela) were listed as the major feed resources in both agro ecological areas. But the contribution of improved forages and local beverage by products were minimal. Natural pasture is the major feed resources especially in wet season. However, crop residues and stubble grazing (aftermath grazing) were reported to be the major sources of feed during the dry season. Thus, natural pasture, crop residues and stuble grazing (aftermath grazing) were the major feed resources of the study areas, which consistent with previous reports of Dawit et al. (2013) for Adami-Tulu Jiddo-Kombolcha district of East Shewa Zone of Oromia Regional State and that of Adugna (2012) for Ethiopian highlands. The study also identified commonly occurring grass species such as Pennisetum clandestinum,
Eragrostis tenuifolia, Cynodon dactaylon, Digitaria abyssinica, Andropogon abyssinicus, Eulisine jaegeri, Pennisetum sphacelatum, Pennisetum thunbergii and Sporobolus pyramidalis. Similarly, among the legume species Trifolium rueppellianum, Medicago polymorpha and wild Vicia sativm were reported to be the most common ones.

The study also revealed that the quality of grazing land is deteriorating due to disappearance of better quality and palatable species of grasses, expansion of invasive plants such as Raphanus raphanistrum and Partinium hysterophorus, and overgrazing and depletion of soil caused by shrinkage of grazing areas as a result of expansion of crop land at the expense of grazing land (Table 5).

Table 5: Cuases for depletion of quality of pasture land as ranked by surveyed households

\begin{tabular}{lcccc}
\hline \multirow{2}{*}{ Possible causes and Agro ecologies } & \multicolumn{4}{c}{ Rank } \\
\cline { 2 - 5 } & $\mathbf{1}^{\text {st }}$ & $\mathbf{2}^{\text {nd }}$ & $\mathbf{3}^{\text {rd }}$ & Index \\
\hline High land & $50(83.3)$ & $6(10.0)$ & $4(6.7)$ & 0.641 \\
$\quad$ Disappearance of better spp. & $4(6.7)$ & $46(76.7)$ & $10(16.7)$ & 0.317 \\
$\quad$ Expansion of invasive plants & $6(10.0)$ & $8(13.3)$ & $46(76.7)$ & 0.222 \\
$\quad$ Depletion of soil & & & & \\
\hline Mid high land & $75(50.0)$ & $43(28.7)$ & $32(21.3)$ & 0.381 \\
$\quad$ Disappearance of better spp. & $48(32.0)$ & $62(41.33)$ & $40(26.7)$ & 0.342 \\
Expansion of invasive plants & $27(18.0)$ & $45(30.0)$ & $78(52.0)$ & 0.277 \\
$\quad$ Depletion of soil & & & & \\
\hline
\end{tabular}

\section{Estimated Annual Feed Balance}

Estimated feed DM obtained from private grazing land, crop residue and stubble grazing (aftermath grazing) per surveyed household is shown in Table 6. The amount of feed DM obtained from private grazing lands of surveyed households of highland was significantly higher than $(P<0.01)$ that of mid altitude. This could be atributed to larger area of grazing land holding per households of highland than mid-altitude areas, whereas the estimated amount of crop residues produced per household was significantly higher $(P<0.05)$ for the mid-altitude than the highland area. This could be due to larger area of maize cultivation that yields larger biomass than other creal crops per hectare (Dirriba et al., 2011). But, the estimated feed DM obtained from stubble (aftermath) grazing seems to be similar $(P>0.05)$ between the two agro-ecologies. 
Table 6: Estimated annual feed DM that can be produced from private holdings per household.

\begin{tabular}{ccccc}
\hline \multirow{2}{*}{ Agro ecology } & \multicolumn{3}{c}{ Estimated annual supply t/hh by source } \\
\cline { 2 - 5 } & Grass land & Crop Residue & Aftermath & Total \\
\hline Highland & $1.29 \pm 0.12$ & $8.55 \pm 0.67$ & $1.71 \pm 0.1$ & 11.55 \\
Mid altitude & $0.89 \pm 0.07$ & $11.20 \pm 0.42$ & $1.81 \pm 0.06$ & 13.89 \\
Average & 1.00 & 10.44 & 1.78 & 13.22 \\
Significance & $* *$ & $* * *$ & $\mathrm{NS}$ & $* *$ \\
\hline
\end{tabular}

\section{Contribution of Major Feed Resources}

Figure 1 shows the proportional contribution of major feed resources to the annual feed supply per household. Private grazing land contributes only about $11.17 \%$ and $6.41 \%$ of annual feed DM per household in highland and mid altitude areas, respectively. On the other hand, the potential contribution of crop residues was the largest contributing about 74 and $81 \%$ of the annual feed supply in the highland and mid-altitude area, respectively. After math (stubble) grazing was estimated to be the second largest portion of annual feed supply per households of the two agro ecologies. A similar report in which grazing land, crop residues and after math grazing contributed $11.9,63.8$ and $12.5 \%$, respectively, was reported by Yeshitila (2008) for Alaba district in southern Ethiopia.

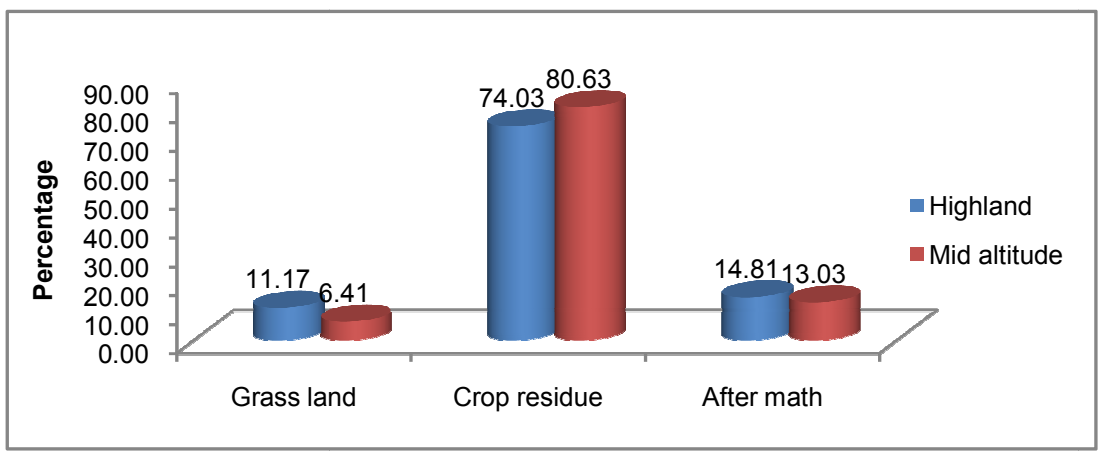

Figure 1: Contribution major feed resources to livestock demand per households

\section{CONCLUSIONS}

The study showed that feed shortage, diseases, shortage of labour, low genetic potential of local animals and water scarcity were the major constraints limiting livestock production in both agro ecologies in decreasing order of importance. Overall, the study revealed shortage of feed supply and that the available feed resources are dominated by poor quality crop residues, aftermath grazing and low quality pasture. This is reflected in low growth, production and reproduction performance of animals. The presence of high proportion of clover in the natural pasture causes animal health problem such as bloating when fed wet and at a young age. Thus, the following recommendations are forwarded for improving livestock production in the study areas.

Livestock development programs in the area should address the chronic feed shortage of the study areas through integration of forage production into crop farming system, sustainable conservation, proper storage, processing and proper utilization of available feed resources. The eradication of invasive noxious plants that is invading grass land needs due attention. The problem of bloating as a result of feeding Trifolium species at young stage of the plant should be alleviated by adjusting the grazing time, wilting of the forage and overall feeding management.

\section{Conflict of Interest}

Conflict of interest none declared.

\section{Acknowledgements}

The authors wish to acknowledge Ethiopian Ministry of Education for financial support through Jimma and Wollega Universities that enabled execution of this study. Special thanks to Offices of Agriculture of Horro and
Guduru districts and all field staffs involved in this study for their tireless support during the entire the study period.

\section{REFERENCES}

Abdinasir, I., (2000). Smallholder dairy production and dairy technology adoption in the mixed farming system in Arsi Highland, Ethiopia. PhD Thesis presented to Humboldt University, Berlin, Germany.

Adugna Tolera., Roger, C.M, Arthur, L.G., Tilahun, S. and Tegene, N. (2000). Nutritional constraints and future prospects for goat production in east Africa. In: R.C. Merkel, G. Abebe and A.L. Goetsch (eds.). The Opportunities and Challenges of Enhancing Goat Production in East Africa. Proceedings of a conference held at Debub University, Awassa, Ethiopia.

Adugna Tolera., Said, A.N. (1994). Assessment of feed resources in Wolayita Sodo. Ethiopian Journal of Agricultural Science 14: 69-87.

Adugna Tolera, (2012). Potential for Development of Alternative Feed Resources in Ethiopia. An Assessment Report prepared for ACDI/VOCA. Addis Ababa Ethiopia, pp. 20

Ahmed Hassen., Abule Ebro., Mohammed Kurtu. and Treydte, A.C. (2010). Livestock feed resources utilization and management as influenced by altitude in the Central Highlands of Ethiopia. Livestock Research for Rural Development 22(12).

Ayantu Mekonen., Taddele Dessie. and Yoseph Mekasha. (2013). Performance evaluation of and design of breeding strategy for Horro cattle breed in Western Oromia, Ethiopia. A dessertation submitted to Animal and Range Sciences of Haramaya University Ethiopia.

Ayele Abebe., Amare Haileslassie. and Banerjee, S. (2012) Small - holder farms livestock management practices and their implications on livestock water productivity in mixed crop-livestock systems in the highlands of Blue Nile basin: 
Kassahun Gurmessa et alo,

A case study from Fogera, Diga, and Jeldu districts (Ethiopia). MSc, Thesis submited to Hawasa University, College of Agriculture.

Ayele Solomon., Assegid Workalemahu., Jabbar, M.A. Ahmed, M.M. and Belachew Hurissa. (2003). Livestock marketing in Ethiopia: A review of structure, performance and development initiatives. Socio-economics and Policy Research Working Paper 52. ILRI (International Livestock Research Institute), Nairobi, Kenya. 35 pp.

Bedassa Eba., Amare Hailesilasie. and Getachew Animut, (2012). Study of smallholder farms livestock feed sourcing and feeding strategies and their implication on livestock water productivity in mixed crop-livestock systems in the highlands of the Blue Nile basin, Ethiopia. A Thesis Submitted to the School of Animal and Range Sciences, School of Graduate Studies Haramaya University.

Belay Duguma., Azage Tegegne and Hegde, B.P. (2012). Smallholder Livestock Production System in Dendi District, Oromia Regional State, Central Ethiopia. Global Veterinaria 8 (5): 472-479.

Behnke, R. (2010). The Contribution of Livestock to GDP in the IGAD Member States", Study Findings, Application of the Methodology in Ethiopia and Recommendations for Extension of the Programme; Odessa Centre, United Kingdom; IGAD LPI Working Paper No. 02-10.

CSA, (2013). Federal democratic republic of Ethiopia Central statistical agency Agricultural sample survey.Volume II Report on Livestock and livestock characteristics (private peasant holdings). Statistical Bulletin, Addis Ababa.

Dawit Asefa., Ajebu Nurfeta., Banereje, S. (2013). Assessment of feed resource availability and livestock production constraints in selected Kebeles of Adami Tullu Jiddo Kombolcha District, Ethiopia. African Journal of Agriculture Resaerch 8(29): 4067-4073.

Dejene Takele. (2014). Assessment of Dairy Cattle Husbandry and Breeding Management Practices of Lowland and Mid-Highland Agro-Ecologies of Borana Zone. Animal and Veterinary Sciences 2(3):62-69.

Demissu Hunde., Fekadu Beyene., and Gemeda Duguma (2013). Early growth and reproductive performance of Horro cattle and their F1 Jersey crosses in and around Horro-Guduru livestock Production and Research Center, Ethiopia. Science, Technology and Art Journal 2(3):134141.

Desta Kelay Belihu., Mlynek J., Nagel U., Herzog H., (2002). Analyses of Dairy Cattle Breeding Practicesin Selected Areas of Ethiopia. Dissertation submited to eingerichtet an der Landwirtschaft-Gärtenerischen Fakultät der Humboldt-Universität zu Berlin.

Diriba Geleti., Adugna Tolera., Ashenafi Mengistu., Mekonen Hailemariam. (2011). Effect of variety of maize on yield of grain, residue fractions and the nutritive value of whole stover, Short communication. Ethiopiopian Journal of Applied Science and Technology 2(2): 91-96.

Edea, Z., Haile, A., Tibbo, M., Sharma, A.K., Sölkner, J. and Wurzinger, M. (2012). Sheep production systems and breeding practices of smallholders in western and southwestern Ethiopia: Implications for designing communitybased breeding strategies. Livestock Research for Rural Development 24(7).

Ethiopian Demographic and Health survey (EDHS), (2012). Central Stastical Agency Addis Ababa, Ethiopia ICF International Calverton, Maryland, USA. pp452

FAO (Food and Agriculture Organization) (1987). Land use, production regions, and farming systems inventory. Technical Report, 3(1). FAO Project ETH/78/003, Addis Ababa, Ethiopia.
Sci. Technol. Arts Res. J., July-Sep 2015, 4(3): 111-116

Gryseels, G. (1988). Role of livestock on a mixed smallholder farmers in Debre Berhan. PhD Dissertation. Agricultural University of Wageningen, the Netherlands.P.149. http://www.fao.org/ag/agp/agpc/doc/counprof/ethiopia/ethi opia.htm.

ILCA (International Livestock Center for Africa), (1990). Livestock systems research manual. No. 12, section 1 Working document. ILCA. Addis Ababa, Ethiopia, pp: 8.

Mohammad Jabbar., Asfaw Negassa and Taye Gidyelew. (2007). Geographic distribution of cattle, shoats populations and their market supply sheds in Ethiopia, Discussion paper No. 2. Improving Market opportunities ILRI (International Livestock Research Institute), Nairobi, Kenya, p54.

Kearl, L.C. (1982). Nutrient requirement of ruminants in developing countries. International Feedstuff Institute, Utah Agricultural Experiment Station. Utah State University, London, USA. P. 381.

Lees, G.C. (1992). Condensed tannins in some forage legumes; Their role in the prevention of ruminant pasture bloat. In: R.W. Hemingway \& P.E. Laks (Ed.) Proceedings of the Second North American Tannin Conference on Plant Polyphenols, Houghton, Michigan, June 17-21, 1991. Plant Polyphenols: Synthesis, Properties, Significance (pp. 915-934). Basic Life Sciences, Vol. 59.

Lemma Gizachew (2002). Crude protein and mineral status of Forages grown on pelvic vertisol of Ginchi, central highlands of Ethiopia. PhD dissertation Presented to the University of the Free State, Bloemfontein.

Majak, W., McAllister, T.A., McCartney, D., Stanford, K., Cheng K.J. (2003). Bloat in cattle. Alberta Agriculture and Rural development Canada.

Buzuayehu Tefera. (2006). People and dams: Environmental and socio-economic changes induced by a reservoir in Fincha'a watershed, western Ethiopia. PhD Thesis, Wageningen University, The Netherlands.

Shiferaw Bekele (1991). Crop livestock production in the Ethiopian highlands and effects on sustainability of mixed farming: a case study of Ada district, Debrezeit. M.Sc. Thesis. Agricultural University of Norway, Oslo, Norway.

Shitahun Mulu., Kefelegn Kebede., Azage Tegene. (2009). Feed Resources Availability, Cattle Fattening Practices and Marketing System in Bure Woreda, Amhara Region, Ethiopia. A thesis of Master of Science Degree in Livestock Production and Pastoral Development.

Solomon Zewudu., Biniyam Kassa., Bilatu Agza., Ferede Alemu., Gaddissa Muleta. (2014). Smallholder Cattle production systems in Metekel zone, North West Ethiopia. Research Journal of Agriculture and Environmental Management 2(3):151-157.

Statistical Packages for the Social Sciences (SPSS, version 17) (1996) Cary, North Carolina, USA.

Tegene, N., Dinku, G. and Moahmmed, B. (2015). Assessment of potential of natural pasture and other feed resources in sweet potato production system of Shebedino district, Sidama zone, SNNPR, Ethiopia. International Journal of Livestock Production 6(8): 91-98.

Yeshitila Admassu., Tessema Zewdu and Azage Tegene. (2008). Availability of livestock feed resources in Alaba Woreda, Southern Ethiopia. In: Proceedings of the 16th annual conference of the Ethiopian Society of Animal Production (ESAP) held in Addis Ababa, Ethiopia, October 8 to 10, 2008.

Zelalem Yilma. (1999). Smallholder Milk Production Systems and Processing Techniques in the Central Highlands of Ethiopia. M.Sc. Thesis. Swedish University of Agricultural Sciences, Uppsala, Sweden, $67 \mathrm{p}$. 